\title{
EVALUASI DAN OPTIMALISASI INSTALASI PENGOLAHAN AIR MINUM (IPA I) SUNGAI SENGKUANG PDAM TIRTA PANCUR AJI KOTA SANGGAU
}

\author{
Joni Hermanto ${ }^{1}$, Winardi Yusuf, ST. M. $T^{1}$, Dian Rahayu Jati, ST. M.Si ${ }^{1}$ \\ ${ }^{1}$ Program Studi Teknik Lingkungan, Fakultas Teknik, Universitas Tanjungpura, Pontianak \\ Email : adxleo_19@yahoo.com
}

\begin{abstract}
ABSTRAK
Kualitas air produksi yang masih berwarna kemerah-merahan menjadi masalah yang dihadapi di IPA I Sungai Sengkuang PDAM Tirta Pancur Aji Kota Sanggau khususnya bila pada musim kemarau. Tujuan dari penelitian ini yaitu, mengevaluasi kinerja unit operasi dan proses IPA I Sungai Sengkuang PDAM Tirta Pancur Aji Kota Sanggau, dan memberikan rekomendasi optimalisasi berdasarkan hasil evaluasi IPA I Sungai Sengkuang PDAM Tirta Pancur Aji untuk memenuhi kebutuhan air minum di wilayah Kota Sanggau.

Tahapan penelitian ini meliputi analisa kualitas air baku, evaluasi kondisi eksisting instalasi dan optimalisasi kinerja unit operasi dan proses pengolahan instalasi, analisa kualitas air produksi, dan hasil optimalisasi unit instalasi. Kualitas air baku yang tidak sesuai dengan mutu air kelas I PP RI Nomor 82 Tahun 2001 yaitu Colliform 240/100 ml, kekeruhan 66 NTU, warna 321 Pt.Co, dan besi 0,89 mg/L. Kualitas air minum yang tidak sesuai dengan Kepmenkes RI No. 492/Menkes/Per/IV/2010 yaitu warna 23 Pt.Co, DO 4,8 mg/L, dan pH 4,82. Upaya optimalisai IPA I Sungai Sengkuang PDAM Tirta Pancur Aji Kota Sanggau yaitu, dilakukan perencanaan bak pengumpul air baku dengan dimensi yaitu $\mathrm{P}=1,75 \mathrm{~m}$, $\mathrm{L}=1,4 \mathrm{~m}$, dan $\mathrm{T}=1 \mathrm{~m}$. Mendesain ulang bak koagulasi dengan dimensi yaitu $\mathrm{P}=1 \mathrm{~m}, \mathrm{~L}=1 \mathrm{~m}$, dan $\mathrm{T}=1 \mathrm{~m}$, mengganti sistem pembubuhan koagulan dengan dozing proporzional, serta mengganti bak pembubuh koagulan dengan kapasitas 500 Liter. Pada unit flokulasi yaitu dengan mengatur bukaan pintu air untuk memperkecil headloss atau tinggi muka air di kompartemen I dan kompartemen II masing-masing menjadi $0,003 \mathrm{~m}$. Mendesain ulang bak sedimentasi dengan $\mathrm{P}=6 \mathrm{~m}$, dan $\mathrm{L}=2 \mathrm{~m}$, mengganti pipa settler yang sudah korosi, menambah 2 pipa outlate, dan menambah tube settler. Merancang ulang media filter menjadi dual media filter, dengan ketebalan antrhasit $=0,75 \mathrm{~m}$, pasir silika=0,75 m, dan kerikil=0,5 $\mathrm{m}$, dan menambah satu unit bak filtrasi dengan dimensi yaitu $\mathrm{P}=1,25 \mathrm{~m}, \mathrm{~L}=1,15 \mathrm{~m}$, dan $\mathrm{T}=6 \mathrm{~m}$.
\end{abstract}

Kata kunci: Evaluasi, IPA, Optimalisasi

\section{ABSTRACT}

The quality of water whose colour is red especially in dry season still becomes a problem for IPA I Sungai Sengkuang of Water Company Tirta Pancur Aji Sanggau. The research aimed to evaluate work of operation unit and process of IPA I Sungai Sengkuang of Water Company Tirta Pancur Aji Sanggau and to give good recommendation according to evaluation result of IPA I Sungai Sengkuang of Water Company Tirta Pancur aji Sanggau to fulfill water needs in Sanggau.

The research covered raw water quality, evaluation of the existing instalasion condition and optimalization of workofnoperation unit and instalation process, analysisn of water quality, and result of optimalization of work of instalation unit. The quality of the raw water is not in line with the first class water quality in Indonesian Government Regulation Number 82 Year 2001 that is Colliform 240/100 ml, turbidity $66 \mathrm{NTU}$, colour $321 \mathrm{Pt}$.Co, and zinc 0,89 mg/l. The quality of water which is not according to decision of ministry of health in Indonesian Number 492/menkes/Per/IV/2010 is colour 23 Pt.Co, DO 4,8 $\mathrm{mg} / \mathrm{l}$, and $\mathrm{pH} \mathrm{4,82}$. The effort to optimalize IPA I Sungai Sengkuang of Water Company Tirta Pancur aji Sanggau is by planning to have cistern with dimension $L=1,75 \mathrm{~m}, W=1,4 \mathrm{~m}$, and $H=1 \mathrm{~m}$. In addition, IPA I Sungai Sengkuang of Water Company Tirta Pancur aji Sanggau needs to redesign coagulation tub with dimension $L=1 \mathrm{~m}, W=1 \mathrm{~m}$, and $H=1 \mathrm{~m}$. Morover, it necessary for IPA I Sungai Sengkuang of Water Company Tirta Pancur aji Sanggau to change coagulant affixing system into dozing proporzional, and to change the coagulant tub into 500 liters in capacity. In flocculation unit, it is necessary to adjust water gate to limit headloss or water level in compartement I and II with 0,003 m. Furthermore, it is needed to redesign sedimentation tub with $L=6 \mathrm{~m}$, and $W=2 \mathrm{~m}$, change rusted outlate pipes, add two outlate pipes, and tube settler. Finally, it is sugested to redesign media filters to dual media filter with antrhasit 
thickness $=0,75 \mathrm{~m}$, silica sand $=0,75 \mathrm{~m}$, and gravel $=0,5 \mathrm{~m}$, and to add another one unit of filtration tub with dimension $L=1,25 \mathrm{~m}, W=1,15 \mathrm{~m}$, and $H=6 \mathrm{~m}$.

\section{Keywords: Evaluation, IPA, Optimalization}

\section{PENDAHULUAN}

Air merupakan salah satu faktor penting dalam penentuan kebutuhan hidup manusia. Pemanfaatan air sebagai air bersih dan air minum tidak dapat dilakukan secara langsung, akan tetapi membutuhkan proses pengolahan terlebih dahulu. Pengolahan dilakukan agar air tersebut memenuhi standar sebagai air bersih maupun air minum. Faktor kualitas air baku sangat menentukan efisiensi pengolahan. Faktor kualitas air baku dapat meliputi warna, kekeruhan, $\mathrm{pH}$, kandungan logam, dan lain-lain. Untuk melakukan proses pengolahan tersebut dibutuhkan suatu instalasi yang sesuai dengan kuantitas dan kualitas yang diinginkan.

Perusahaan Daerah Air Minum (PDAM) Tirta Pancur Aji Sanggau merupakan perusahaan yang melayani kebutuhan air minum di Kota Sanggau. PDAM Tirta Pancur Aji memiliki 3 IPA yang berada di Kota Sanggau, yaitu IPA Liku, IPA Laverna/Projal, dan IPA Sungai Sengkuang. IPA Sungai Sengkuang merupakan IPA yang paling tua umurnya, IPA ini dibangun pada tahun 1982, dan sudah diadakan penambahan 2 unit pengolahannya, yaitu masing-masing IPA II pada tahun 1996, dan IPA III pada tahun 2012. IPA I merupakan IPA tertua dengan kapasitas produksi 20 liter/detik, sampai saat ini masih terus beroperasi, namun belum pernah dilakukan evaluasi terhadap kinerja dari IPA tersebut. Faktor usia IPA yang sudah cukup tua dan kondisi IPA yang sudah banyak mengalami kerusakan, serta kualitas air produksi yang berwarna kemerahmerahan menjadi masalah yang dihadapi di IPA I Sungai Sengkuang khususnya bila pada musim kemarau.

Salah satu upaya untuk meningkatkan kualitas air produksi PDAM Tirta Pancur Aji, perlu dilakukan beberapa perubahan pada unit IPA dengan mengadakan evaluasi kinerja unit bangunan IPA. Hal ini penting karena evaluasi ini belum pernah dilakukan, sehingga dapat mengetahui permasalahan yang ada pada IPA tersebut. Evaluasi yang akan dilakukan ditinjau dari kualitas dan kuantitas air baku dan air produksi, serta kinerja unit- unit bangunan IPA tersebut. Sehingga diharapkan mampu memberikan saran dan masukan yang perlu untuk mengatasi permasalahan yang ada di unit pengolahan air minum pada IPA I Sungai Sengkuang.

\section{TINJAUAN PUSTAKA}

Pada umumnya Instalasi Pengolahan Air minum merupakan suatu sistem yang mengkombinasikan proses koagulasi, flokulasi, sedimentasi, filtrasi, dan desinfeksi serta dilengkapi dengan pengontrolan proses juga instrument pengukuran yang dibutuhkan Instalasi ini harus didesain untuk menghasilkan air yang layak dikonsumsi masyarakat bagaimanapun kondisi cuaca dan lingkungan. Selain itu, sistem dan subsistem dalam instalasi yang akan didesain harus sederhana, efektif, dapat diandalkan, tahan lama, dan murah dalam pembiayaan (Kawamura, 1991).

Pemilihan masing-masing unit operasi yang digunakan dipengaruhi oleh berbagai faktor seperti jenis dan karakteristik air, variasi debit air, kualitas hasil olahan yang diinginkan, pertimbangan kemudahan dalam operasi dan pemeliharaan yang berkaitan dengan ketersedian teknologi dan tenaga terampil serta aspek ekonomis menyangkut biaya yang harus disediakan untuk pembangunan instalasi serta biaya operasionalnya. Sedangkan pengolahan air secara 
khusus yang disesuaikan dengan kondisi sumber air baku dan atau keperluan/ peruntukan penggunaannya dapat dilakukan diantaranya dengan reverse osmosis, ion exchange, adsorbsi, dan pelunakan air (Darmasetiawan, 2004).

Standar kualitas air bersih dan minum yang berlaku di Indonesia saat ini adalah Peraturan Pemerintah Nomor 82 Tahun 2001 tanggal 14 Desember 2001 tentang Pengelolaan Kualitas Air dan Pengendalian Pencemaran Air serta Keputusan Menteri Kesehatan (Kepmenkes) RI No. 492/Menkes/Per/IV/2010.

\section{METODOLOGI PENELITIAN}

\section{A. Pengumpualan Data}

Pengumpulan data bertujuan untuk mendapatkan data yang diperlukan dan kemudian dilakukan analisa. Data yang dikumpulkan terdiri dari data primer dan sekunder.

\section{B. Analisa Kualitas Air Baku}

Analisa terhadap air baku mengacu pada standar kualitas atau baku mutu air bersih yang terdapat pada peraturan pemerintah No. 82 tahun 2001 tentang pengelolaan kualitas air dan pengendalian pencemaran air. Parameter yang akan di uji pada air baku yaitu parameter kekeruhan, warna, besi (Fe), DO, pH, raksa(Hg), Colliform.

\section{Evaluasi Kondisi Eksisting Instalasi dan Optimalisasi Kinerja Unit Proses Pengolahan Instalasi}

Membandingkan kondisi esksisting instalasi dengan standar peraturan yang berlaku dan kriteria desain tiap unit. Dimensi unit akan dibandingkan dengan kriteria desain unit. Kualitas air pada proses pengolahan di instalasi di hitung efisiensi dari kinerja unit bangunan instalasi apakah masih berjalan dengan baik, parameter yang akan diuji meliputi kekeruhan dan warna. Evaluasi dilakukan pada unit intake, koagulasi, flokulasi, sedimentasi, filtrasi, dan reservoir (desinfeksi).

\section{Analisa Kualitas Air Produksi}

Analisa terhadap kualitas air produksi mengacu pada standar kualitas atau baku mutu air minum yang terdapat pada Keputusan Menteri Kesehatan No. 492 tahun 2010. Parameter yang akan di uji pada air baku yaitu parameter kekeruhan, warna, besi ( $\mathrm{Fe}), \mathrm{DO}, \mathrm{pH}$, raksa(Hg), Klorin bebas.

\section{E. Rencana Optimalisasi Unit Proses Pengolahan Instalasi}

Hasil dari evaluasi dan rencana optimalisasi terhadap kinerja semua unit operasi dan proses pengolahan air pada IPA I PDAM Tirta Pancur Aji Kota Sanggau akan ditampilkan pada sub Bab ini supaya lebih ringkas.

\section{GAMBARAN UMUM LOKASI PENELITIAN}

IPA Sungai Sengkuang merupakan IPA pertama yang dimiliki oleh PDAM Tirta Pancur Aji Kota Sanggau. IPA ini dibangun pada tahun 1982 dengan kapasitas produksi 20 liter/detik, dan sudah mengalami penambahan IPA sebanyak 2 unit IPA paket, masing-masing IPA II dengan kapasitas 10 liter/detik pada tahun 1996 dan IPA III dengan kapasitas 50 liter/detik pada tahun 
2012, dengan demikian IPA Sungai Sengkuang memiliki total produksi air bersih sebesar 80 liter/detik.

Berikut ini adalah gambar layout IPA I Sungai Sengkuang dan gambar potongan melintang dari IPA I Sungai Sengkuang yang telah digambar ulang, dapat dilihat pada Gambar 1 dan Gambar 2.

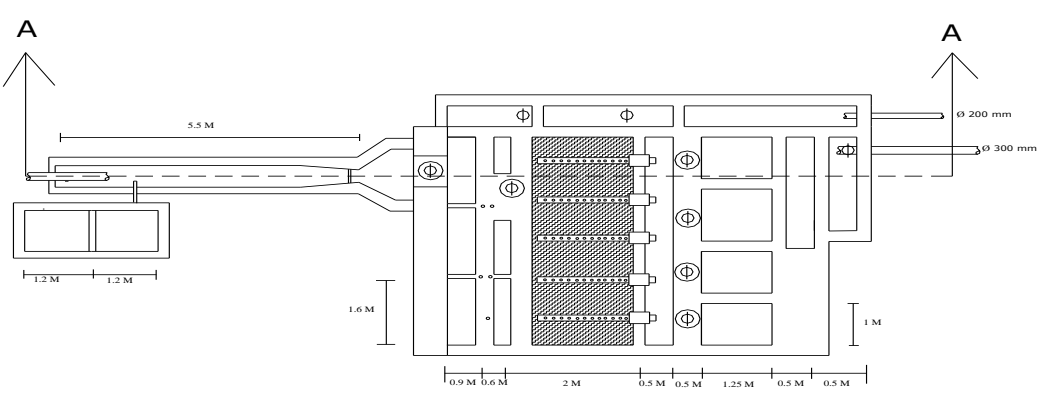

Gambar 1. Layout IPA I Sungai Sengkuang

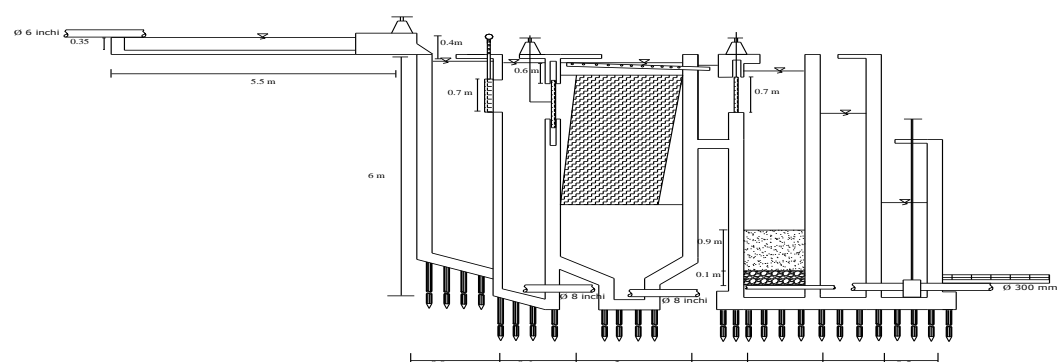

Gambar 2. Potongan A-A IPA I Sungai Sengkuang

\section{HASIL DAN PEMBAHASAN}

\section{A. Analisa Kualitas Air Baku}

Berikut ini adalah hasil pemeriksaan kualitas air baku Sungai Sengkuang pada tahun 2013 berdasarkan baku mutu air kelas I PP RI Nomor 82 Tahun 2001 yang dapat dilihat pada Tabel 1.

Tabel 1. Hasil Pemeriksaan Kualitas Air Baku IPA I Sungai Sengkuang

\begin{tabular}{|c|l|c|c|c|c|}
\hline No & PARAMETER & SATUAN & $\begin{array}{c}\text { BAKU } \\
\text { MUTU }\end{array}$ & HASIL & METODE \\
\hline 1 & Coliform* & $/ 100 \mathrm{ml}$ & 100 & 240 & MPN Tabung Ganda \\
\hline 3 & Kekeruhan* & NTU & 25 & 66 & Turbiditimeter \\
\hline 4 & Warna* & Pt.Co & 15 & 321 & Spectrofotometri \\
\hline 5 & Besi $(\mathrm{Fe})^{*}$ & $\mathrm{mg} / \mathrm{L}$ & 0,3 & 0,89 & SM Ed.21 Th 2005 \\
\hline 6 & DO & $\mathrm{mg} / \mathrm{L}$ & 6 & 4,6 & DO Meter \\
\hline 7 & Merkuri $(\mathrm{Hg})$ & $\mathrm{mg} / \mathrm{L}$ & 0,001 & $\leq 0,0002$ & AAS \\
\hline 8 & $\mathrm{pH}$ & & 69 & 5,97 & Spectrofotometri \\
\hline
\end{tabular}

Keterangan: $\left({ }^{*}\right)$ : Parameter kualitas air diatas baku mutu

Pada air baku Sungai Sengkuang diketahui besarnya kandungan Coliform diatas baku mutu, yaitu sebesar 240/100 mL. Tingginya kandungan Coliform pada air baku disebabkan karena banyaknya penduduk di sekitar Sungai Sengkuang yang membuat jamban di tepian sungai 
tersebut untuk keperluan MCK. Kandungan Coliform yang diatas baku mutu kualitas air baku ini menunjukkan bahwa air Sungai Sengkuang tersebut sudah tercemar oleh bakteri E.Coli. Dari parameter mikrobiologi tersebut air Sungai Sengkuang tidak dapat dijadikan sebagai air baku untuk IPAM tersebut karena tidak termasuk mutu air kelas I yaitu air baku air minum dan atau peruntukan lain yang mempersyaratkan mutu air yang sama pada PP RI Nomor 82 Tahun 2001.

Dari hasil pengujian nilai kekeruhan air baku Sungai Sengkuang diatas baku mutu, yaitu sebesar 66 NTU. Tingginya nilai kekeruhan pada air baku Sungai Sengkuang disebabkan karena sudah terjadi pencemaran dibagian hulu sungai oleh perkebunan kelapa sawit yang merusak hutan dibagian hulu sungai yang mengakibatkan air sungai menjadi keruh.

Dari hasil pengujian diketahui konsentrasi warna air baku sangat tinggi diatas baku mutu kualitas air baku, yaitu sebesar $321 \mathrm{Pt}$.Co. Konsentrasi warna yang tinggi pada air baku Sungai Sengkuang dikarenakan air sungai sengkuang tersebut termasuk air gambut sehingga memiliki komsentrasi warna yang tinggi.

Dari hasil pengujian diketahui kandungan besi pada air baku Sungai Sengkuang diatas baku mutu, yaitu sebesar $0,89 \mathrm{mg} / \mathrm{L}$. Air Sungai Sengkuang termasuk air gambut sehingga memiliki kandungan besi yang cukup tinggi.

\section{B. Evaluasi Kondisi Eksisting Instalasi dan Optimalisasi Kinerja Unit Proses Pengolahan Instalasi}

\section{Raw Water Intake(Penyadap Air Baku)}

Intake yang digunakan di IPA Sungai Sengkuang adalah intake terapung. Intake ini digunakan untuk menyuplai air baku ke seluruh IPA Sungai Sengkuang yang berjumlah 3 IPA dengan kapasitas total IPA 80 Liter/detik. Digunakan 2 buah pompa dengan kapasitas masingmasing pompa sebesar 50 liter/detik dengan head pompa sebesar $60 \mathrm{~m}$. Data hasil perhitungan evaluasi terhadap unit intake IPA Sungai Sengkuang dapat dilihat pada Tabel 2.

Tabel 2. Hasil Perhitungan Evaluasi Unit Intake

\begin{tabular}{|c|l|c|c|c|}
\hline No & \multicolumn{1}{|c|}{ Parameter } & Kriteria Desain & Nilai & Keterangan \\
\hline 1 & Kapasitas pompa & $(10-20 \%)$ kapasitas olahan & 100 & Tidak sesuai \\
\hline 2 & Head pompa & $>$ Head rencana & 120 & Sesuai \\
\hline 3 & Diameter pipa intake & $\mathrm{D}=0,72 \mathrm{Q}^{0,5}$ & 8 inci & Sesuai \\
\hline 4 & Diameter pipa IPA I & $\mathrm{D}=0,72 \mathrm{Q}^{0,5}$ & 6 inci & Sesuai \\
\hline
\end{tabular}

Berdasarkan perhitungan pada intake IPA Sungai Sengkuang ini, ukuran pipa sudah sesuai dengan kriteria desain, hanya pompa penyadap air baku kapasitas pompanya diatas Kriteria desain, namun hal ini tidak berpengaruh terhadap kinerja dari masing-masing IPA Sungai Sengkuang, dikarenakan sudah ada pengatur debit yang masuk untuk tiap IPA.

\section{Koagulasi}

Sistem koagulasi IPA I adalah berupa terjunan atau sistem pengadukan hidrolis, Bahan koagulan yang digunakan adalah tawas atau Aluminium Sulfat $\mathrm{Al}_{2}\left(\mathrm{SO}_{4}\right)_{2}$. Dosis yang digunakan di IPA I Sungai Sengkuang sebanyak 50 kg tawas/hari. Konsentrasi larutan koagulan adalah $10 \%$ yang dilakukan dengan cara melarutkan $1 \mathrm{~kg}$ tawas padat dengan 10 Liter air pelarut. Data hasil perhitungan evaluasi terhadap unit koagulasi IPA Sungai Sengkuang dapat dilihat pada Tabel 3. 
Tabel 3. Hasil Perhitungan Evaluasi Unit Koagulasi

\begin{tabular}{|c|c|c|c|c|}
\hline No & Parameter & Kriteria Desain & Nilai & Keterangan \\
\hline 1 & Waktu detensi bak koagulasi ( $t d)$ & 60 detik & 43 detik & Sesuai \\
\hline 2 & waktu detensi bak pembubuh (td) & 8-24jam & 84 jam & Tidak sesuai \\
\hline 3 & Gradien kecepatan ( G ) & $400-1000$ detik $^{-1}$ & 319,67 detik $^{-1}$ & Tidak sesuai \\
\hline 4 & $\mathrm{G} \times \mathrm{td}$ & $20000-30000$ & $13.745,81$ & Tidak sesuai \\
\hline
\end{tabular}

Koagulasi tipe hidrolis dengan menggunakan sistem terjunan ini menghasilkan nilai $\mathrm{G}$ dan Gtd yang tidak sesuai dengan kriteria desain. Nilai $G$ dan Gtd masih dibawah nilai kriteria desain hal ini dapat mengakibatkan pencampuran koagulan tidak homogen. Waktu detensi bak koagulasi masih sesuai kriteria desain, hal ini cukup efektif memungkinkan pencampuran koagulan dan air baku dapat berjalan dengan optimal. Besarnya nilai waktu detensi dari bak pembubuh koagulan, menunjukkan bahwa volume bak pembubuh koagulan dapat menampung larutan koagulan dalam waktu yang cukup lama, karena volume bak pembubuh koagulan jauh lebih besar dari volume larutan koagulan yang dibutuhkan. Besarnya waktu detensi pada bak pembubuh koagulan yaitu 84 jam tidak akan menjadi masalah apabila dalam pengoperasiannya bak pembubuh koagulan tersebut maksimal 24 jam, dikarenakan apabila larutan koagulan disimpan didalam bak pembubuh dalam waktu yang cukup lama, maka zat koagulan dalam larutan tersebut akan mengendap. Cukup diperlukan 1 bak pembubuh koagulan saja untuk IPA I.

Optimalisasi kinerja unit koagulasi yaitu mendesain ulang unit koagulasi dengan dimensi $\mathrm{P}=1 \mathrm{~m}, \mathrm{~L}=1 \mathrm{~m}$, dan $\mathrm{T}=1 \mathrm{~m}$, merancang bak pengumpul air baku untuk menaikan ketinggian terjunan menjadi $1 \mathrm{~m}$, dengan dimensi $\mathrm{P}=1,75 \mathrm{~m}, \mathrm{~L}=1,4 \mathrm{~m}, \mathrm{~T}=1 \mathrm{~m}$.

\section{Flokulasi}

Unit flokulasi ini menggunakan sistem pengadukan hidrolis, berupa buffle chanel aliran horizontal. Unit flokulasi memiliki enam bak dengan sistem Hidrolika Helicoidal Up dan Down Flow Gravitation. Data hasil perhitungan evaluasi unit flokulasi IPA Sungai Sengkuang dapat dilihat pada Tabel 4.

Tabel 4. Hasil Perhitungan Evaluasi Unit Flokulasi

\begin{tabular}{|c|c|c|c|c|c|c|c|c|c|}
\hline \multirow[b]{2}{*}{ NO } & \multirow[b]{2}{*}{ Parameter } & \multirow[b]{2}{*}{ Kriteria Desain } & \multicolumn{6}{|c|}{ Nilai } & \multirow[b]{2}{*}{ Keterangan } \\
\hline & & & $\begin{array}{c}\text { Kompartemen } \\
1\end{array}$ & $\begin{array}{c}\text { Kompartemen } \\
\|\end{array}$ & $\begin{array}{c}\text { Kompartemen } \\
\text { III }\end{array}$ & $\begin{array}{c}\text { Kompartemen } \\
\text { IV }\end{array}$ & $\begin{array}{c}\text { Kompartemen } \\
\mathrm{V}\end{array}$ & $\begin{array}{c}\text { Kompartemen } \\
\text { VI }\end{array}$ & \\
\hline 1 & Waktu detensi (td) & 15 - 45 menit & 43,65 & 43,65 & 43,65 & 29 & 29 & 29 & Sesuai \\
\hline 2 & Gradien kecepatan (G) & $10-60$ detik $^{-1}$ & 45,88 & 45,88 & 35,53 & 35,48 & 35,48 & 25,1 & Sesuai \\
\hline 3 & Gxtd & $10^{4}-10^{5}$ & $120.030,33$ & $120.030,33$ & $92.952,87$ & $62,247,88$ & $62,247,88$ & $43.810,78$ & Kompartemen I dan II Tidak sesuai \\
\hline
\end{tabular}

Optimalisasi untuk unit flokulasi yaitu memperkecil nilai Gtd pada kompartemen I dan II dengan memperkecil nilai headloss atau tinggi muka air dengan cara mengatur bukaan pintu air pada kompartemen tersebut menjadi 0,003 $\mathrm{m}$.

\section{Sedimentasi}

Data hasil perhitungan evaluasi unit sedimentasi IPA Sungai Sengkuang dapat dilihat pada Tabel 5. 
Tabel 5. Hasil Perhitungan Evaluasi Unit Sedimentasi

\begin{tabular}{|c|l|c|c|c|}
\hline NO & \multicolumn{1}{|c|}{ Parameter } & Kriteria Desain & Nilai & Keterangan \\
\hline 1 & Rasio panjang lebar & $3: 1-5: 1$ & 2,425 & Tidak sesuai \\
\hline 2 & Surface loading rate & $(60-150) \mathrm{m}^{3} / \mathrm{m}^{2}$. hari & $198,62 \mathrm{~m}^{3} / \mathrm{m}^{2}$.hari & Tidak sesuai \\
\hline 3 & Kecepatan pada settler & $(0,05-0,13) \mathrm{m} / \mathrm{menit}$ & $0,1428 \mathrm{~m} / \mathrm{menit}$ & Tidak sesuai \\
\hline 4 & Weir loading rate & $(90-360) \mathrm{m}^{3} / \mathrm{m}^{2}$. hari & $356,28 \mathrm{~m}^{3} / \mathrm{m}^{2}$. hari & Sesuai \\
\hline 5 & Reynold number & $<2000$ & 53,3 & Sesuai \\
\hline 6 & Froude number & $>10^{-5}$ & $2,88 \times 10^{-5}$ & Sesuai \\
\hline 7 & Waktu detensi bak & $<120$ menit & 48 menit & Sesuai \\
\hline
\end{tabular}

Nilai rasio panjang lebar tidak sesuai dengan kriteria desain, yaitu dibawah kriteria desain, hal ini dapat mempengaruhi nilai surface loading rate. Nilai surface loading rate atau beban permukaan bak sedimentasi yang diatas kriteria desain sangat mempengaruhi efisiensi penghilangan partikel dari air. Kecepatan pada settler diatas kriteria desain, hal ini dapat mengakibatkan penggerusan pada permukaan settler dan menyebabkan aliran menjadi tidak laminer. Nilai beban weir normal, nilai ini dibutuhkan pada zona sedimentasi agar alirannya tetap laminer. Waktu detensi bak masih normal, waktu yang dibutuhkan cukup untuk terjadinya proses pengendapan flok-flok yang terbentuk dalam proses sebelumnya. Nilai bilangan Reynold dan bilangan Froud masih sesuai kriteria desain, hal ini menandakan aliran air laminer dan uniform.

Optimalisasi kinerja unit sedimentasi yaitu dengan mendesain ulang unit sedimentasi dengan dimensi $\mathrm{P}=2 \mathrm{~m}, \mathrm{~L}=6 \mathrm{~m}$, dan $\mathrm{T}=6 \mathrm{~m}$, menambah tube settler dan 2 pipa outlate, serta mengganti pipa outlate yang sudah korosi.

\section{5. $\quad$ Filtrasi}

Tipe filter yang digunakan pada IPA 1 Sungai Sengkuang adalah filter pasir cepat dengan media filter tunggal/ single media yang beroperasi secara gravitasi. Data hasil perhitungan evaluasi unit Filtrasi IPA Sungai Sengkuang dapat dilihat pada Tabel 6.

Tabel 6. Hasil Perhitungan Evaluasi Unit Filtrasi

\begin{tabular}{|c|l|c|c|c|}
\hline NO & \multicolumn{1}{|c|}{ Parameter } & Kriteria Desain & Nilai & Keterangan \\
\hline 1 & Dimensi & & & \\
\hline 2 & $\bullet$ Lebar & $3-6 \mathrm{~m}$ & 1 & Tidak sesuai \\
\hline 3 & $\bullet$ Rasio panjang \& lebar & $2: 1-4: 1$ & 1,25 & Tidak sesuai \\
\hline 4 & $\bullet$ Kedalaman & $5,5-7,5$ & 6 & Sesuai \\
\hline 5 & $\bullet$ Luas area & $25-80 \mathrm{~m}^{2}$ & 1,25 & Tidak sesuai \\
\hline 6 & Kecepatan filtrasi & & & \\
\hline 7 & $\bullet$ Normal & $100-475$ & $345,6 \mathrm{~m}^{3} / \mathrm{m}^{2}$.hari & Sesuai \\
\cline { 4 - 5 } 8 & $\bullet$ Backwash & $3 / \mathrm{m}^{2} \cdot$ hari & $691 \mathrm{~m}^{3} / \mathrm{m}^{2}$.hari & Tidak sesuai \\
\hline 9 & Kedalaman & & & Tidak sesuai \\
\hline 10 & $\bullet$ Media filter (Pasir silika) & $0,75 \mathrm{~m}$ & 0,95 & Tidak sesuai \\
\hline 11 & $\bullet$ Media penyangga (kerikil ) & $0,5 \mathrm{~m}$ & 0,1 & \\
\hline
\end{tabular}

Lebar dan rasio panjang \& lebar bak filter terlalu kecil dan tidak sesuai kriteria desain, hal ini dapat mempengaruhi kecepatan filtrasi. Untuk kedalaman bak sudah sesuai kriteria desain. Luas permukaan bak filter tidak sesuai dengan kriteria desain, akan tetapi kecepatan filtrasi sudah sesuai dengan kriteria desain. Kecepatan filtrasi merupakan salah satu parameter kunci yang 
digunakan untuk menentukan luas permukaan bak. Semakin besar kecepatan filtrasi, maka luas bak yang dibutuhkan semakin kecil. Unit filtrasi ini tidak dapat bekerja dengan baik saat backwash ( 2 unit tidak beroperasi ) karena nilai kecepatan filtrasi pada saat backwash berdasarkan perhitungan desain terlalu besar diatas kriteria desain. Tebal media filter sedikit lebih besar dari kriteria desain, sedangkan tebal media penyangga lebih kecil dari kriteria desain. Hal ini dapat berpengaruh terhadap kualitas air produksi, dikhawatirkan pasir silika sebagai media filter akan ikut terbawa dengan aliran air, karena media penyangga yang digunakan terlalu tipis.

Optimalisasi unit filtrasi pada IPA I Sungai Sengkuang yaitu dengan cara tidak mengubah ukuran desain unit filtrasi yang sudah ada, hanya dilakukan peningkatan media filter yang semula adalah single media filter, akan ditingkatkan menjadi dual media filter, yaitu penambahan anthrasit $=0,75 \mathrm{~m}$ pada bagian atas media filter, mengatur ulang ketebalan dari media penyangga(kerikil) $=0,5 \mathrm{~m}$ dan lapisan pasir kwarsa $=0,75 \mathrm{~m}$, serta menambah satu bak filtrasi lagi dengan dimensi $P=1,25 \mathrm{~m}, \mathrm{~L}=1,15 \mathrm{~m}$, dan $\mathrm{H}=6 \mathrm{~m}$. Penambahan media filter anthrasit dapat berfungsi untuk menurunkan konsentrasi warna yang tinggi pada air baku.

\section{Desinfeksi}

Desinfektan yang digunakan adalah kaporit, metode pembubuhan kaporit adalah metode dozing proporzional. Kaporit berfungsi untuk membunuh bakteri dan protozoa yang berbahaya di air serta menghambat pertumbuhan lumut. Dosis kaporit yang diberikan yaitu sebesar 2,0 $\mathrm{mg} / \mathrm{Liter}$. Sisa klor di reservoir adalah rata-rata $0,04 \mathrm{mg} / \mathrm{L}$ di bawah standar baku mutu air minum menurut Peraturan Menteri Kesehatan Republik Indonesia No. 492/MENKES/PER/2010 yaitu $5 \mathrm{mg} / \mathrm{L}$.

\section{Reservoir}

Reservoir dengan kapasitas $150 \mathrm{M}^{3}$ digunakan untuk menampung air olahan dari IPA I. Dari perhitungan diketahui kapasitas dan waktu detensi reservoir 2,13 Jam masih sesuai dengan kriteria desain(td>1 Jam), hal ini memungkinkan air produksi tersimpan dalam waktu yang optimal dalam reservoir sebelum didistribusikan kepada pelanggan.

\section{ANALISA KUALITAS AIR PRODUKSI}

Berikut ini adalah hasil pemeriksaan kualitas air produksi IPA I Sungai Sengkuang pada tahun 2013 berdasarkan Kepmenkes RI No. 492/Menkes/Per/IV/2010 dapat dilihat pada Tabel 7.

Tabel 7. Hasil Pemeriksaan Kualitas Air produksi IPA I Sungai Sengkuang

\begin{tabular}{|c|l|c|c|c|c|}
\hline No & \multicolumn{1}{|c|}{ PARAMETER } & SATUAN & $\begin{array}{c}\text { BAKU } \\
\text { MUTU }\end{array}$ & HASIL & METODE \\
\hline 1 & Kekeruhan & NTU & 5 & 1 & Turbiditimeter \\
\hline 2 & Warna* & Pt.Co & 15 & 23 & Spectrofotometri \\
\hline 3 & Besi (Fe) & $\mathrm{mg} / \mathrm{L}$ & 0,3 & 0,18 & SM Ed.21 Th 2005 \\
\hline 4 & DO* & $\mathrm{mg} / \mathrm{L}$ & 6 & 4,8 & DO Meter \\
\hline 5 & Merkuri $(\mathrm{Hg})$ & $\mathrm{mg} / \mathrm{L}$ & 0,001 & $\leq 0,0002$ & AAS \\
\hline 6 & pH* & & $6,58,5$ & 4,82 & Spectrofotometri \\
\hline 7 & Klorin bebas $(\mathrm{Cl} 2)$ & $\mathrm{mg} / \mathrm{L}$ & 5 & 0,04 & Spectrofotometri \\
\hline
\end{tabular}

Keterangan: $\left({ }^{*}\right)$ : Parameter kualitas air tidak sesuai baku mutu 
Dari hasil pengujian diketahui konsentrasi warna produksi masih diatas baku mutu kualitas air minum, yaitu sebesar 23 Pt.Co. Secara fisik kondisi air produksi dapat dilihat tampak berwarna kemerah-merahan. Konsentrasi warna yang tinggi pada air olahan dapat disebabkan karena unit proses filtrasi yang tidak bekerja dengan baik. Dari hasil pengujian kualitas air, parameter warna pada unit sedimentasi sudah mengalami penurunan dan dibawah baku mutu kualitas air minum, namun setelah melewati unit filtrasi konsentrasi warna jauh meningkat dan diatas baku mutu kualitas air.

Dari hasil pengujian diketahui nilai DO pada air produksi masih dibawah baku mutu kualitas air minum, yaitu sebesar 4,8. Hal ini menandakan kualitas air produksi masih belum bagus, karena semakin kecil nilai DO maka semakin buruk kualitas air tersebut.

Dari hasil pengujian diketahui nilai $\mathrm{pH}$ air produksi masih dibawah baku mutu kualitas air minum berdasarkan Kepmenkes RI No. 492/Menkes/Per/IV/2010, yaitu sebesar 4,82. Hal ini menunjukkan bahwa kualitas air produksi bersifat asam. $\mathrm{pH}$ air produksi yang masih dibawah baku mutu kualitas air minum disebabkan karena kurangnya dosis kapur yang digunakan sebagai bahan netralisan. Selain itu $\mathrm{pH}$ air produksi yang rendah dapat juga disebabkan oleh dosis koagulan yang terlalu besar.

\section{Rencana Optimalisasi Unit Proses Pengolahan Instalasi}

Berikut ini adalah gambar layout optimalisasi IPA I Sungai Sengkuang, beserta gambar potongan melintang dari optimalisasi IPA I Sungai Sengkuang, dapat dilihat pada Gambar 3 dan Gambar 4.

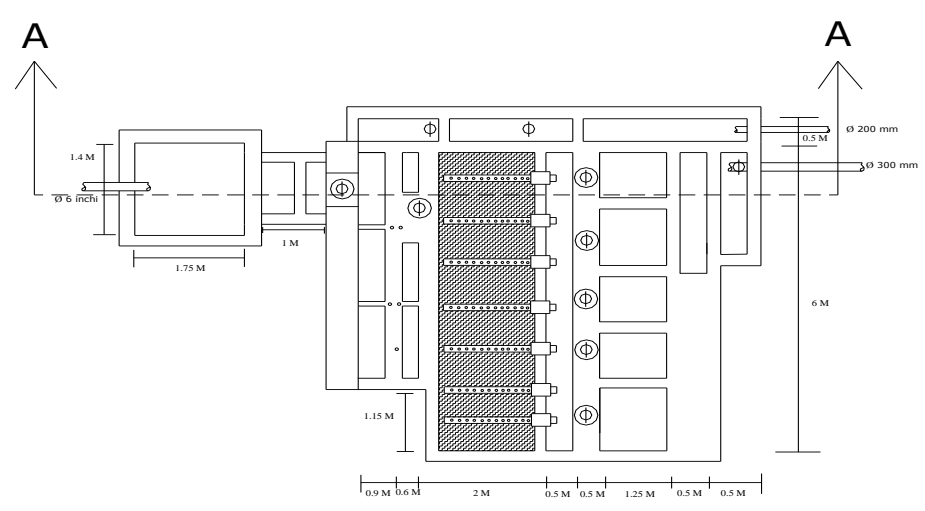

Gambar 3. Layout IPA I Sungai Sengkuang

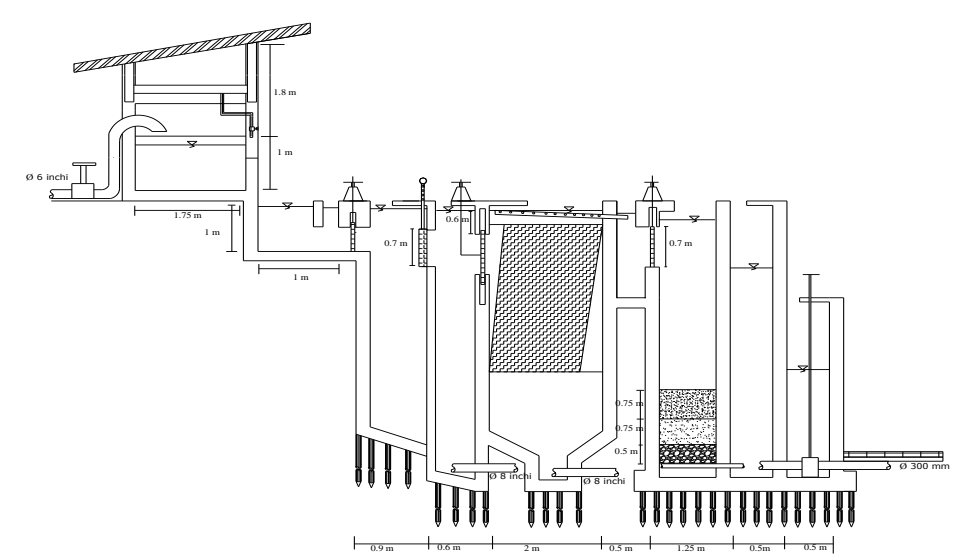

Gambar 4. Potongan A-A IPA I Sungai Sengkuang 


\section{PENUTUP}

\section{A. Kesimpulan}

1. Kualitas air baku yang tidak sesuai dengan mutu air kelas I PP RI Nomor 82 Tahun 2001 yaitu Coliform 240/100 ml, kekeruhan 66 NTU, warna 321 Pt.Co, dan besi 0,89 mg/L, sedangkan kualitas air minum yang tidak sesuai dengan Kepmenkes RI No. 492/Menkes/Per/IV/2010 yaitu warna 23 Pt.Co, DO 4,8 mg/L, dan pH 4,82.

2. Upaya optimalisasi IPA I Sungai Sengkuang PDAM Tirta Pancur Aji Kota Sanggau adalah dengan mengadakan perubahan-perubahan dan perlakuan khusus pada unit instalasi yang memiliki masalah. Perencanaan optimalisasi pada tiap unit instalasi diantaranya yaitu :

a. Dibangun bak pengumpul air baku dengan dimensi yaitu $P=1,75 \mathrm{~m}, \mathrm{~L}=1,4 \mathrm{~m}$, dan $\mathrm{T}=1$ m.

b. Mendesain ulang bak koagulasi dengan dimensi yaitu $P=1 \mathrm{~m}, \mathrm{~L}=1 \mathrm{~m}$, dan $\mathrm{T}=1 \mathrm{~m}$. Mengganti sistem pembubuhan koagulan dengan dozing proporzional, serta mengganti bak pembubuh koagulan dengan kapasitas 500 Liter.

c. Pada unit flokulasi yaitu dengan mengatur bukaan pintu air untuk memperkecil headloss atau tinggi muka air di kompartemen I dan kompartemen II masing-masing menjadi 0,003 m.

d. Mendesain ulang bak sedimentasi dengan $\mathrm{P}=6 \mathrm{~m}$, dan $\mathrm{L}=2 \mathrm{~m}$. Mengganti pipa settler yang sudah korosi, menambah 2 pipa settler, dan menambah media pengendap tube settler.

e. Merancang ulang media filter menjadi dual media filter, dengan ketebalan antrhasit=0,75 $\mathrm{m}$, pasir silika=0,75 $\mathrm{m}$, dan kerikil=0,5 $\mathrm{m}$. Menambah satu unit bak filtrasi dengan dimensi yaitu $P=1,25 \mathrm{~m}, \mathrm{~L}=1,15 \mathrm{~m}$, dan $\mathrm{T}=6 \mathrm{~m}$.

\section{Ucapan Terima Kasih}

Dalam kesempatan ini, penulis menyampaikan terima kasih yang sebesar-besarnya kepada : Bapak Winardi Yusuf, ST.,M.T selaku Dosen Pembimbing Utama , Ibu Dian Rahayu Jati, ST.,M.Si., selaku Dosen Pembimbing Pendamping serta kepada Dosen Penguji Ibu Rizki Purnaini, ST.,MT dan Ibu Yulisa Fitianingsih ST.,MT sebagai penguji utama dan penguji pendamping.

\section{Referensi}

Daramasetiawan. 2004. Teori dan Perencanaan Instalasi Pengolah Air. Jakarta: Ekamitra Engineering.

Kawamura, Susumu. 1991. Integrated Design of Water Treatment Facilities. New York: John Wirley \& sons inc.

PERMENKES RI(Peraturan Menteri Kesehatan Republik Indonesia) Nomor 492/MENKES/PER/IV/2010 tentang Persyaratan Kualitas Air Minum.

PP RI ( Peraturan Pemerintah Republik Indonesia) No.82 Tahun 2001 tentang Pengelolaan Kualitas Air dan Pengendalian Pencemaran Air. 